Reprod. Nutr. Dévelop., 1986, 26 (2 A), 487-501.

\title{
Properties of an LH-stimulable adenylate cyclase in plasma membranes of interstitial cells from rat testis
}

\author{
Danièle SALTARELLI, M. Paloma DE LA LLOSA-HERMIER $\left({ }^{*}\right)\left({ }^{1}\right)$, \\ C. HERMIER $\left({ }^{*}\right)$
}

Laboratoire d'Enzymologie, C.N.R.S., 91190 Gif sur Yvette, France.

$\left(^{*}\right)$ Laboratoire des Hormones Polypeptidiques (ER282), C.N.R.S., 91190 Gif/Yvette.

Summary. We studied the effect of guanyl nucleotides, divalent cations and luteinizing hormone ( $\mathrm{LH}$ ) on the regulation of adenylate cyclase (AC) in partially purified plasma membranes obtained from isolated interstitial cells of the rat testis. AC was activated to different degrees by guanosine triphosphate (GTP) and GMP-P(NH)P ; the latter was about 10 times more active than the former. Enzyme activation by GTP was biphasic; the nucleotide was rapidly hydrolysed by membrane preparation. Activation by GMP-P(NH)P was hysteretic, requiring about $20-30 \mathrm{~min}$ to reach steady state; this lag-time was not dependent on nucleotide concentration. GDP $\beta S$ did not stimulate $A C$ activity. Delayed addition of GDP $\beta S$ to a GMP-P(NH)P-stimulated enzyme at 17 min resulted in a drop of AC activity although the activity 40 min later was higher than that obtained by mixing both nucleotides at the time the reaction was initiated. This result was incompatible with the formation of a truly irreversible, active form of the enzyme in the presence of GMP-P(NH)P.

The effect of $\mathrm{LH}$ on $\mathrm{AC}$ depended on guanine nucleotides and $\mathrm{Mg}^{2+}$. $\mathrm{LH}$ and GMP-P(NH)P acted synergically. Dose-response curves showed that apparent LH affinity was not modified by the presence of GMP-P $(\mathrm{NH}) \mathrm{P}$. LH accelerated the slow rate of activation of GMP-P(NH)P. The stimulation of $\mathrm{AC}$ by $\mathrm{LH}$ was closely dependent on $\mathrm{Mg}^{2+}$ concentrations ; $\mathrm{LH}$ diminished the apparent $\mathrm{Mg}^{2+}$ requirement.

Plasma membranes from rat testicular interstitial cells are an excellent model for the study of $A C$ regulation by $\mathrm{LH}$.

\section{Introduction.}

Gonadotropins act by binding to their respective receptors and stimulating adenylate cyclase $(\mathrm{AC})$ on the target cell. Most experimental data concerning the effects of luteinizing hormone (LH) on AC activity have been obtained in the

(1) To whom all correspondence should be addressed.

Abbreviations.

GMP-P(NH)P : guanyl-5'-yl imidodiphosphate.

GDP $\beta S$ : guanosine 5'0-(2 thiodiphosphate).

EGTA : ethylene glycol bis-(3 aminoethyl ether)-N-N', tetraacetic acid. 
ovary (Birnbaumer and Kirchick, 1983), and there are few on LH stimulation of this enzyme in testicular interstitial cells. Dufau et al. (1980) reported that the number of GMP-P(NH)P binding sites in these cell membranes was increased by LH. Levi et al. (1982a, b) showed that guanine nucleotide mediated desensitization of $\mathrm{AC}$ in cell-free preparations from a Leydig cell tumor. However, it seems that there are differences between the ovary and the testis as to structural requirements for receptor binding of $\mathrm{LH}$ (De La Llosa-Hermier et al., 1977) and the mechanism by which $\mathrm{LH}$ stimulates the $\mathrm{AC}$ complex, i.e. the coupling between receptor occupancy and $A C$ stimulation (Catt and Dufau, 1983 ; Abramowitz et al., 1982). It must be remembered therefore that the results and conclusions obtained with the ovary are not necessarily applicable to testicular interstitial cells and that the regulation of CAMP metabolism may be different in normal and tumor cells.

Using a kinetic approach, we have explored the role of guanyl nucleotides and some divalent cations $\left(\mathrm{Mg}^{2}, \mathrm{Mn}^{2+}\right)$ on the regulation of basal and $\mathrm{LH}$ stimulated $A C$ activities in plasma membranes obtained from a preparation of collagenase-dispersed interstitial cells from the rat testis. This work is a preliminary to further investigation of the influence of the chemical structure of $\mathrm{LH}$ on its regulatory action of the receptor-AC complex.

\section{Material and methods.}

Chemicals. - Highly purified LH $(2 \times$ LH NIH S1) was isolated from ovine pituitary glands in our laboratory by the method of Jutisz and Courte (1968). Collagenase was provided by Worthington and MEM (minimum essential medium salts of Eagle) by Eurobio. ${ }^{3} \mathrm{H}$ cAMP was obtained from CEA (Saclay, France), $\left(\alpha^{32} \mathrm{P}\right)$ adenosine triphosphate (ATP) and $\left(\alpha^{32} P\right)$ guanosine triphosphate (GTP) from Amersham (England). GMP-P(NH)P and the other nucleotides used were from Boehringer (Mannheim). The other products were purchased from Sigma.

Preparation of dispersed interstitial cells from rat testis. - Interstitial cells were isolated as described previously (De La Llosa-Hermier et al., 1980). Briefly, the decapsulated testes of 40-day old Wistar rats were incubated for $20 \mathrm{~min}$ at $37{ }^{\circ} \mathrm{C}$ in MEM buffer ( $\mathrm{pH} 7.4 ; 1$ testis $/ 3 \mathrm{ml}$ ) containing collagenase $(0.5 \mathrm{mg} / \mathrm{ml})$. The tubular mass was allowed to settle and the supernatant was filtered and centrifuged for $5 \mathrm{~min}$ at $300 \times \mathrm{g}$. The cell pellet was resuspended in fresh buffer.

Membrane preparation. - Partially purified membranes from rat testicular interstitial cells were obtained by modification of the procedure described by Mintz et al. (1978). Using a glass-teflon homogenizer, the dispersed cells were broken in icecold $1 \mathrm{mM} \mathrm{NaHCO}$ medium containing dithiothreitol $(1 \mathrm{mM})$, deoxyribonuclease I $(1,600 \mathrm{U} / \mathrm{mg})$ and $\mathrm{Mg}^{2+}(0.2 \mathrm{mM})$. The homogenate $(15 \mathrm{ml})$, containing about $2-4.10^{9}$ cells, was adjusted to a final concentration of $36 \%(W / W)$ with solid sucrose, introduced into a polycarbonate tube and overlaid with an equal volume of sucrose $(34 \%)(W / W)$ in the same bicarbonate medium without deoxyribonu- 
clease. The tubes were centrifuged in a SW 27 Beckman rotor at $60000 \times \mathrm{g}$ for $120 \mathrm{~min}$. The upper phase containing the purified membranes was diluted 10 -fold with bicarbonate medium, then centrifuged at $10000 \times \mathrm{g}$ for $30 \mathrm{~min}$. The pellet was resuspended in bicarbonate medium and stored in liquid nitrogen. As in the ovary, this procedure allowed 8-10-fold purification of plasma membrane interstitial cells.

Adenylate cyclase and GTPase assay. - The standard assay medium (60 $\mu \mathrm{l})$ contained $0.5 \mathrm{mM}$ ATP $+\alpha^{32}$ P ATP $\left(10^{6} \mathrm{cpm}\right), 2 \mathrm{mM} \mathrm{MgCl}, 1 \mathrm{mM}$ cAMP, $50 \mathrm{mM}$ Tris- $\mathrm{HCl}, \mathrm{pH} 7.6$, and an ATP regenerating system $(25 \mathrm{mM}$ phosphocreatine and $1 \mathrm{mg} / \mathrm{ml}$ of creatine phosphokinase). Enzymatic reaction, initiated by the addition of 10 to $20 \mu \mathrm{g}$ of membrane proteins, was performed in a shaking water bath at $32{ }^{\circ} \mathrm{C}$. Reaction was stopped following the procedure of White (1974). The samples were supplemented by $0.2 \mathrm{ml}$ of $0.5 \mathrm{~N} \mathrm{HCl}$, boiled for $6 \mathrm{~min}$, buffered with $0.2 \mathrm{ml}$ of $1.5 \mathrm{mM}$ imidazole, and finally applied on alumina columns. Cyclic AMP was eluted with $3 \mathrm{ml}$ of $10 \mathrm{mM}$ imidazole- $\mathrm{HCl}, \mathrm{pH} 7.6$. Blank values obtained by this procedure were always less than $0.005 \%$ of the total radioactivity applied. The yield was calculated from the previous addition of ${ }^{3} \mathrm{H}$ cAMP.

GTPase activity was determined by the method of Nishizuka et al. (1968).

The protein content was determined by the method of Lowry et al. (1951) using bovine serum albumin as the standard.

\section{Results.}

Effect of guanine nucleotides on cAMP synthesis. - Cyclic AMP accumulation for $30 \mathrm{~min}$ followed a simple saturation law for $\mathrm{Mg}$ ATP concentrations ranged between 0.05 and $1 \mathrm{mM}$ in the presence of $\mathrm{Mg}^{2}+6 \mathrm{mM}$. GMP-P(NH)P $(100 \mu \mathrm{M})$ increased the $V$ max of the enzyme without significant effect on the $K_{m}$ of the catalytic site for Mg ATP (data not shown).

The addition of GTP $\left(10^{-9} \mathrm{M}\right.$ to $\left.10^{-6} \mathrm{M}\right)$ resulted in a slight increase of $\mathrm{AC}$ activity, but further increase of the GTP concentration resulted in a decrease of enzyme activity (fig. 1A). GMP-P(NH)P increased enzyme activity in a doserelated manner. The degree of maximal stimulation obtained varied with the batch of plasma membranes used and could reach 30 times the basal activity. Guanosine $5^{\prime}$-diphosphate (GDP) (data not shown) or its analog, GDP $\beta S$ (fig. 1A), did not change AC activity. When GTP or GDPBS was added simultaneously with GMP-P(NH)P, it competitively inhibited the ability of GMP-P(NH)P to activate the enzyme (fig. 1A, B). Thus, these nucleotides shared a common site of action on $\mathrm{AC}$ activity. In this experiment, the $\mathrm{Ka}$ app (concentration required to half maximally stimulate adenylate cyclase activity) for GMP-P(NH)P was $0.8 \mu \mathrm{M}$ and the $\mathrm{Ki}$ app for GDP $\beta S$ was $0.22 \mu \mathrm{M}$. This competitive effect could be due to a different exchange rate as well as to a difference in thermodynamic affinity.

Measurement of GTP hydrolysis. - There may be several reasons for the biphasic response to GTP concentration, including densensitization of the type 


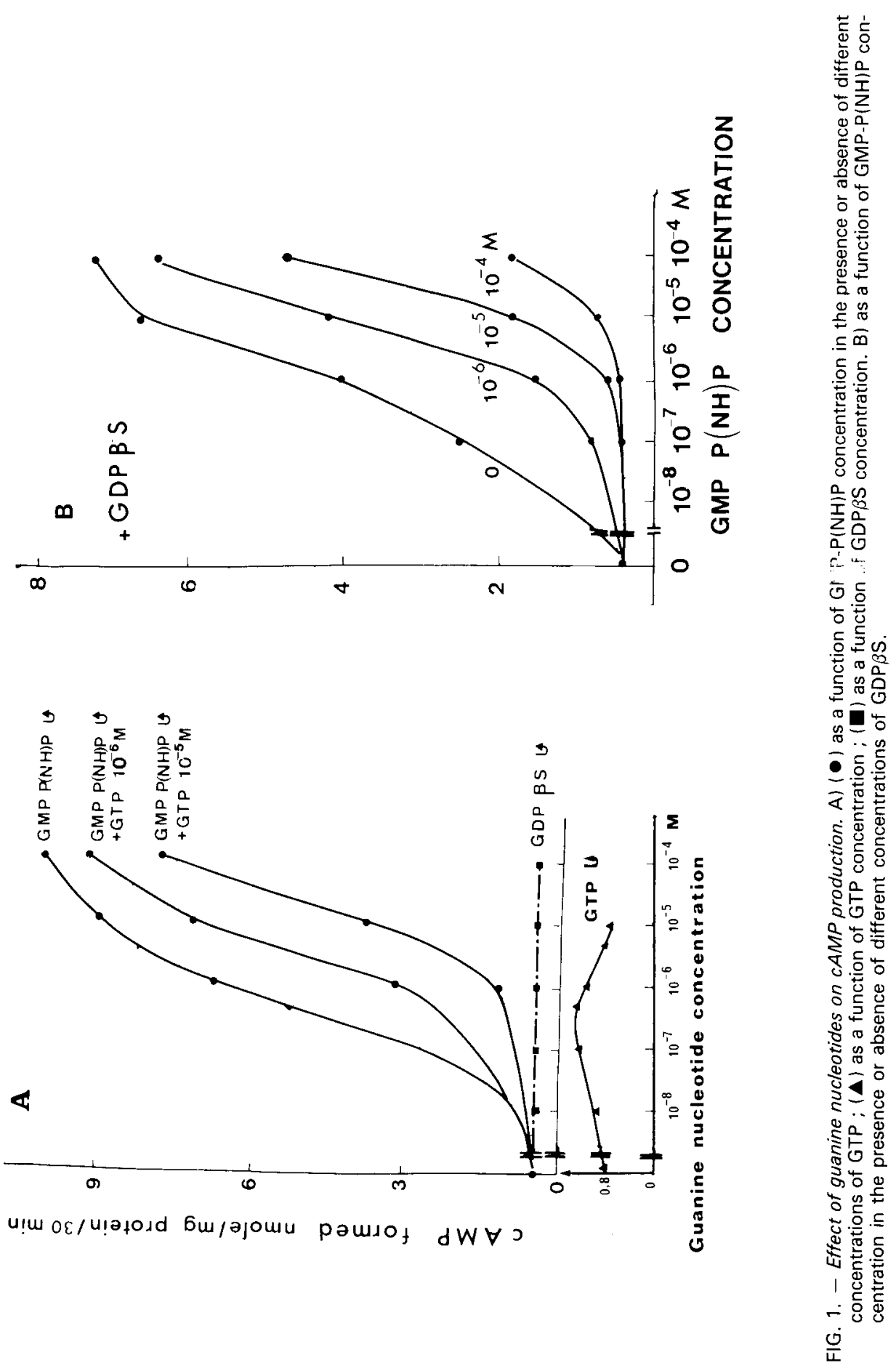


proposed by Ezra and Salomon (1981), receptor-mediated GTP-dependent inhibition of AC (Cooper, 1982), or lack of effect due to GTP hydrolysis.

Figure 2 shows that under standard assay conditions of AC activity, GTP $(0.4 \mu \mathrm{M})$ was rapidly hydrolysed $(70 \%$ in $5 \mathrm{~min})$ and that this hydrolysis was inhibited by ATP and its analog, AMP-P(NH)P. In the presence of AMP-P(NH)P $1 \mathrm{mM}$ or ATP $5 \mathrm{mM}, 50 \%$ of the GTP was hydrolysed after $30 \mathrm{~min}$. GTP hydrolysis was not modified by the presence of an ATP regenerating system (data not shown).

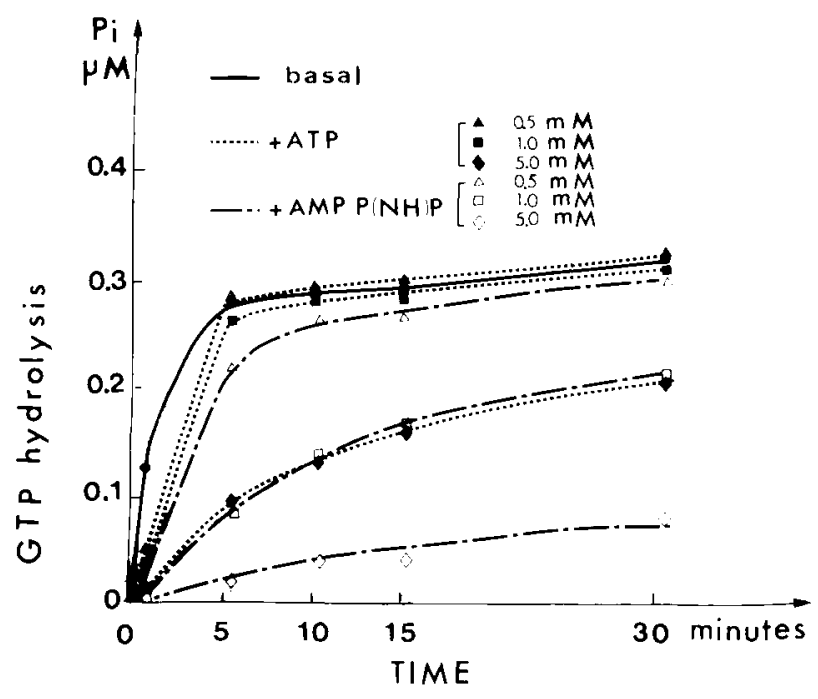

FIG. 2. - Time-course of $\left(\gamma^{32} \mathrm{p}\right)$ GTP hydrolysis. (-) in the absence of adenyl nucleotides $;(\boldsymbol{\Delta}, \mathbf{\square}, \boldsymbol{\prime})$ in the presence of varying concentrations of ATP : $0.5 \mathrm{mM}$, $1 \mathrm{mM}, 5 \mathrm{mM}$ respectively: $(\triangle, \square, \diamond)$ in the presence of varying concentrations of AMP-P(NH)P : $0.5 \mathrm{mM}$, $1 \mathrm{mM}, 5 \mathrm{mM}$ respectively.

On the basis of these findings, it appears that the lack of GTP effect on interstitial cell adenylate cyclase in the rat testis might be at least partly due to the hydrolysis of GTP to GDP.

Kinetics of adenylate cyclase activation in the presence of GMP-P(NH)P. - The time-course of cAMP production in the presence of GMP-P(NH)P is depicted in figure 3 . The production of cAMP was slowly stimulated and up to 20-30 min were needed to reach steady state velocity. After this lag-time, the rate of cAMP production remained constant for $\mathbf{4 0} \mathrm{min}$. The intercept of the extrapolated linear portion with the $x$-axis corresponded to $1 /$ Kobs (Kobs $=$ the activation rate constant); Kobs was particularly low (0.06-0.05 $\left.\mathrm{min}^{-1}\right)$. It should be noted that the membranes exhibited an identical lag-time when GMP-P(NH)P concentrations increased from $10^{-7}$ to $10^{-5} \mathrm{M}$. In membranes preincubated for $15 \mathrm{~min}$ in the presence of GMP-P(NH)P alone, the lag-time decreased but cAMP production remained steady (data not shown).

The lag-time was independent of membrane protein (7-36 $\mu \mathrm{g})$ and Mg ATP $(200-800 \mu \mathrm{M})$ concentrations. The maximal enzyme activity reached was linear with respect to the amount of membrane protein used. Cyclic AMP production at 


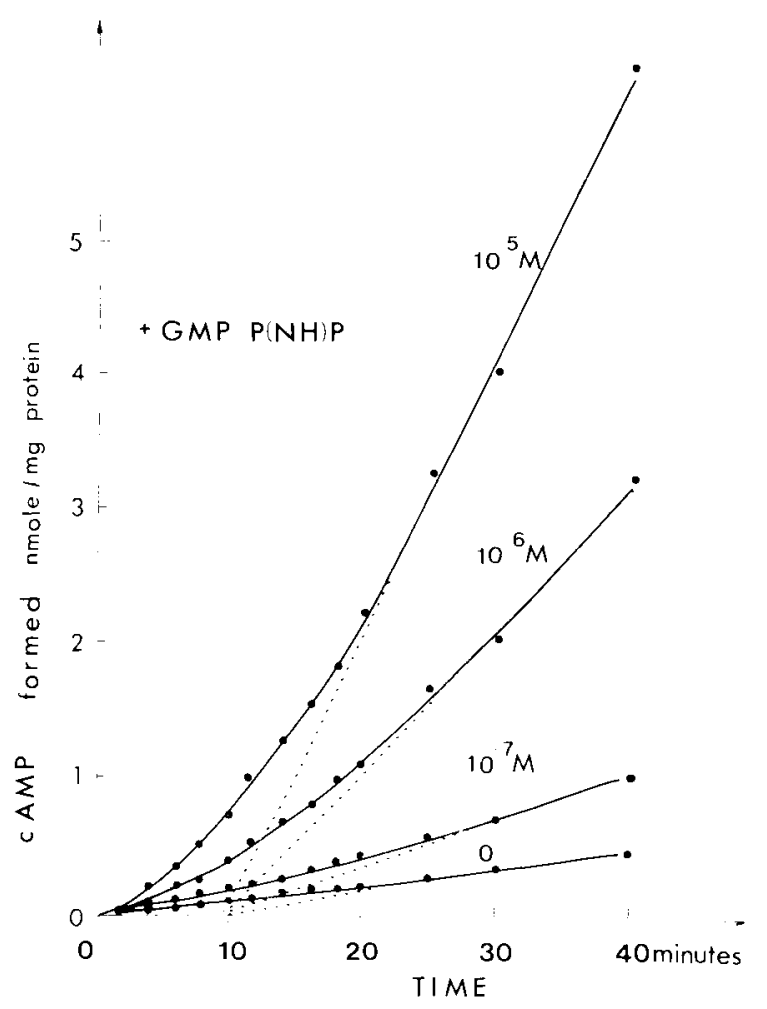

FIG. 3. - Effect of different concentrations of GMP-P(NH)P on the time-course of CAMP production.

steady state velocity increased with Mg ATP substrate concentration and was linear with respect to time for at least $40 \mathrm{~min}$ (data not shown).

Effects of $\angle H$ on adenylate cyclase activity. - LH activated the $A C$ of rat testicular interstitial cells, even without the addition of guanine nucleotide.

Figure 4 depicts the effect of increasing concentrations of $\mathrm{LH}$ (in the presence of different concentrations of GMP-P(NH)P) on cAMP accumulation for $40 \mathrm{~min}$; GMP-P(NH)P did not significantly modify the LH concentration required to obtain half maximal $A C$ activity. The relative stimulation obtained with $\mathrm{LH}$ was similar at all the GMP-P(NH)P concentrations studied. On the other hand, LH did not significantly alter the concentration of GMP-P(NH)P required to obtain half maximal enzyme activity.

$\mathrm{LH}$ also diminished the lag-time observed during the time-course of the stimulation of CAMP accumulation in the presence of GMP-P(NH)P (fig. 5). The value of $K_{o b s}$ and maximal specific activity increased with hormone concentration in a dose-dependent manner. After preincubation of the membranes for 15 min with $\mathrm{LH}$ alone $(10 \mu \mathrm{g} / \mathrm{ml})$, the time required to reach steady state velocity was almost zero (fig. 6). This result may signify that LH binding was kinetically limiting 


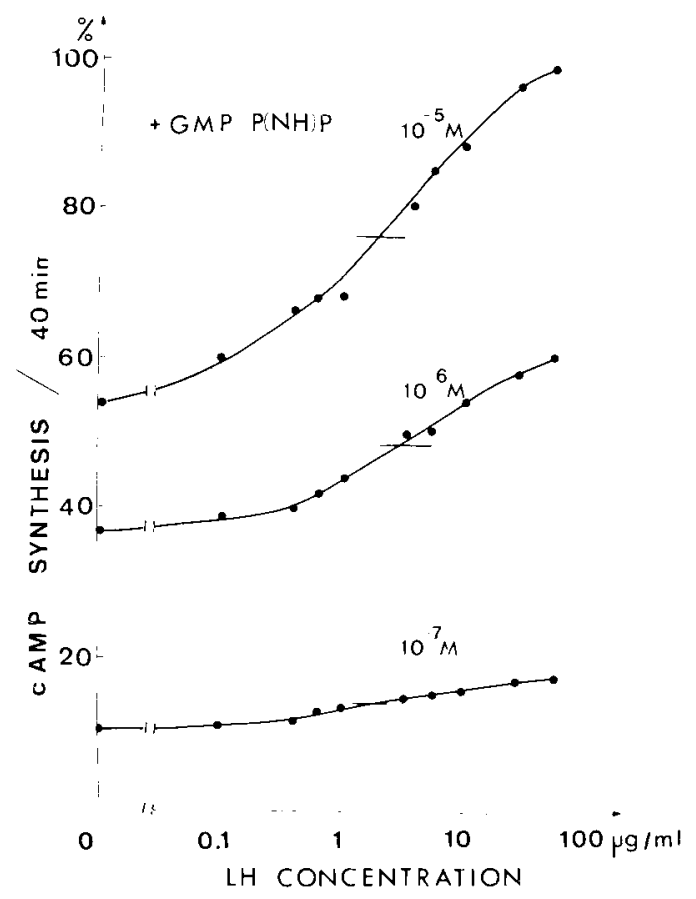

FIG. 4. - Effect of $\angle H$ concentrations on GMP-P(NH)P- stimulated CAMP production. In the assay $L H$ was added at the same time as the plasma membranes.

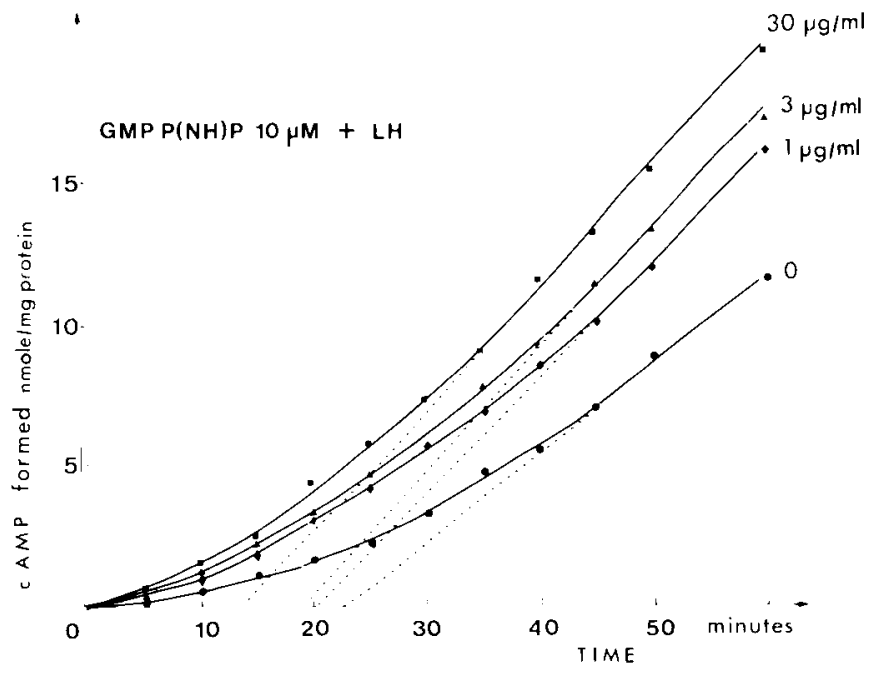

FIG. 5. - Effect of $L H$ concentrations on the time-course of cAMP production by GMP-P(NHIP. $\mathrm{LH}$ was added at the same time as the plasma membranes. 
and/or that, in the absence of GMP-P(NH)P, the hormone-receptor complex could promote the activation of the regulatory component which limited the rate of CAMP production. In membranes preactivated with GMP-P(NH)P alone, the hormone significantly increased maximal activity without any significant lag-time (data not shown).
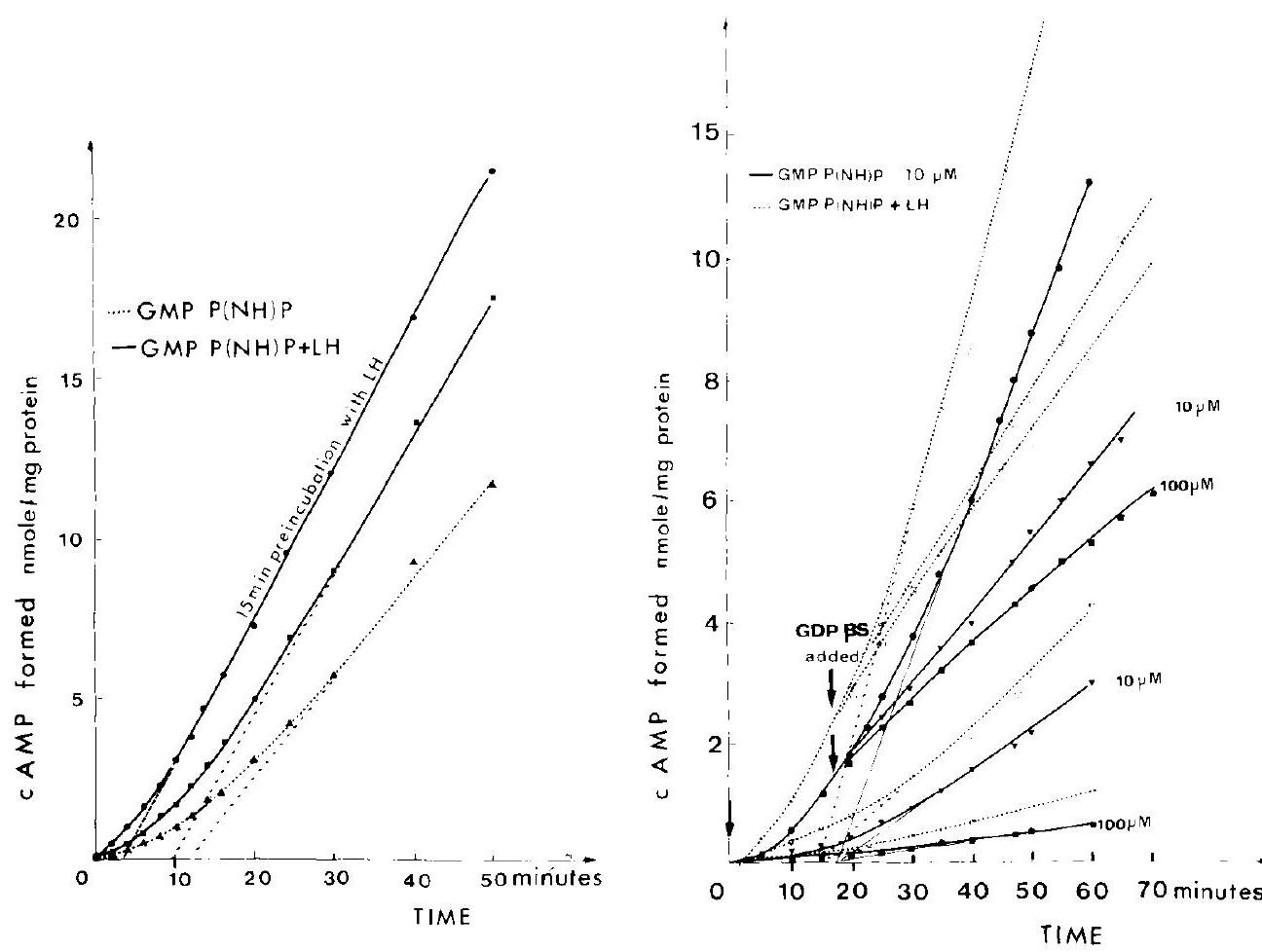

FIG. 6. - Effect of preincubating plasma membranes with or without $L H(10 \mu \mathrm{g} / \mathrm{ml}), 15 \mathrm{~min}$, on the time-course of $c A M P$ production in the presence of $G M P-P(N H) P(10 \mu M)$ and $L H$ (final concentration : $10 \mu \mathrm{g} / \mathrm{ml}$.

FIG. 7. - Effect of GDPBS on the time-course of CAMP production stimulated by GMP-P(NH)P $(10 \mu \mathrm{M})(\bullet)(-) G M P-P(N H) P(10 \mu \mathrm{M})$ and $L H(3 \mu \mathrm{g} / \mathrm{ml})(0)(\ldots)$ GDP $\beta S$ at $10(\nabla, \nabla)$ or $100 \mu \mathrm{M}(\square, \square)$ was added together with GMP-P(NH)P or $17 \mathrm{~min}$ after the addition of GMP-P(NH)P.

Kinetics of adenylate cyclase activation in the presence of combinations of GMP-P(NH)P and GDPBS. - In the other AC systems, GMP-P(NH)P not only stimulated AC more than GTP did but, unlike GTP, caused a persistently activated state of the enzyme (Lefkowitz and Caron, 1975; Schramm and Rodbell, 1975). The nucleotide at its binding site did not seem to be exchangeable after activation.

Figure 7 presents the effect of GDP $\beta S$ on the GMP-P(NH)P-stimulated AC activity of rat testicular interstitial cells; GDPBS at two different concentrations 
(10 and $100 \mu \mathrm{M})$ was added together with GMP-P(NH)P $(10 \mu \mathrm{M})$ at either $t=0$ or $17 \mathrm{~min}$ after initiation of the stimulatory effect of GMP-P(NH)P. The same experiment was carried out in the presence of $\mathrm{LH}$.

If the exchange rate was different from zero, it could be expected that the delayed addition of GDP $\beta S$ would lead to a steady state activity (time-course dependent on the rate of GMP-P(NH)P exchange and the reversal rate of GMP-P(NH)P-stimulated activity) similar to that obtained by mixing GDP $\beta S$ and GMP-P(NH)P at $t=0$. In both the presence and absence of $\mathrm{LH}$ the addition of GDP $\beta S$ at $t=17$ led to a drop in the steady state rate of activation immediately, even though at the end of the experiment it did not reach the steady state obtained by mixing both nucleotides at the time the reaction was initiated.

Stimulatory effects of divalent cations on adenylate cyclase activity. - $\mathrm{Ca}^{2+}$ $\left(10^{-5}\right.$ to $\left.10^{-2} \mathrm{M}\right)$ significantly inhibited basal and GMP-P(NH)P-stimulated AC in interstitial cells from the rat testis. Moreover, EGTA or EDTA stimulated AC activity but the use of high EDTA concentrations $(5 \mathrm{mM})$ inhibited $A C$ activity, probably through $\mathrm{Mg}^{2+}$ chelation (data not shown). Consequently, in standard conditions, we used EGTA $1 \mathrm{mM}$.

We examined the effect of varying concentrations of $\mathrm{Mn}^{2+}$ or $\mathrm{Mg}^{2+}$ on $\mathrm{AC}$ activity assayed in a medium containing $0.5 \mathrm{mM}$ ATP. As shown in figure 8 , basal activity and responsiveness to GMP-P(NH)P and LH were regulated by the concentrations of $\mathrm{Mn}^{2+}$ added ; however, the response to these cations varied. Basal $A C$ activity was 10 -fold higher in the presence of $1 \mathrm{mM} \mathrm{Mn}^{2+}$ than in the presence of $1 \mathrm{mM} \mathrm{Mg}{ }^{2+}$, while the extent of GMP-P(NH)P activation at $1 \mathrm{mM} \mathrm{Mn}^{2+}$ was only 3-fold more than that obtained with $1 \mathrm{mM} \mathrm{Mg}^{2+}$. With $5 \mathrm{mM} \mathrm{Mn}^{2+}$, enzyme activity declined markedly and the extent of activation by GMP-P(NH)P and the hormone became significantly lower than those observed with
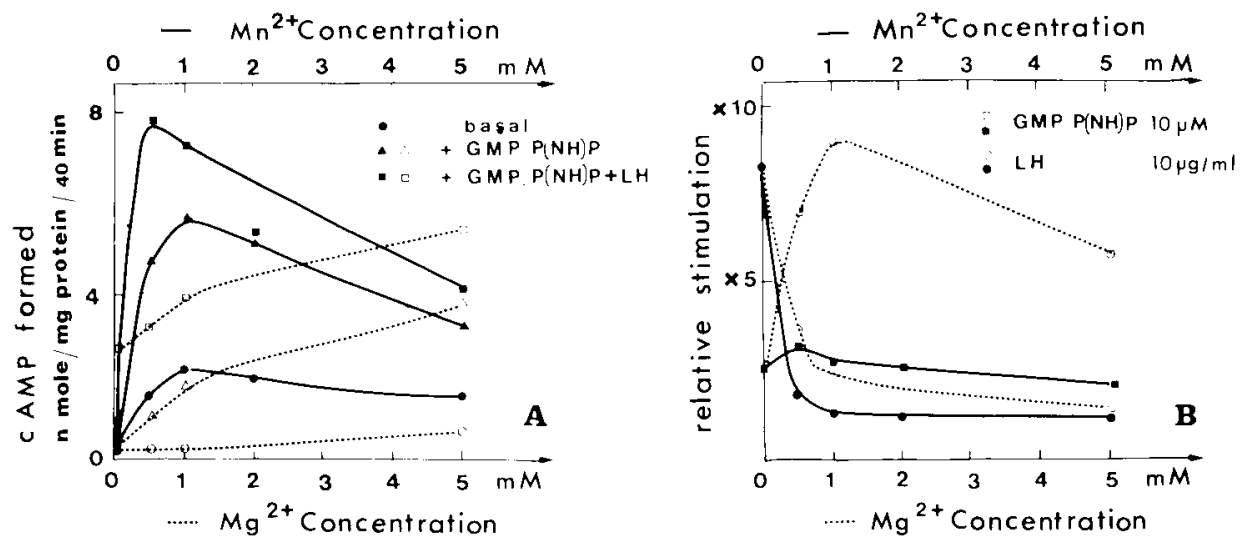

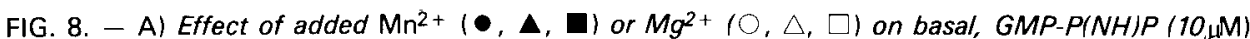
or $G M P-P(N H) P(10 \mu \mathrm{M})+L H(10 \mu \mathrm{g} / \mathrm{ml})$-stimulated cAMP production. B) Relative $G M P-P(N H) P(10 \mu \mathrm{M})$ or $L H(10 \mu \mathrm{g} / \mathrm{ml})$ stimulation of cAMP production as a function of the $\mathrm{Mg}^{2+}$ or $\mathrm{Mn}^{2+}$ added. Incubation was carried out in the presence of ATP $0.5 \mathrm{mM}$. 
$5 \mathrm{mM} \mathrm{Mg}^{2+}$. Analysis of the data in figure 8 also indicates that maximal relative stimulation by GMP-P(NH)P was obtained at $1 \mathrm{mM} \mathrm{Mg}^{2+}$ or $0.5 \mathrm{mM} \mathrm{Mn}^{2+}$, whereas increasing the $\mathrm{Mg}^{2+}$ concentration resulted in a decrease of maximal relative stimulation due to $\mathrm{LH}$. As reported by Ambramowitz and Birnbaumer (1982), the values of the added $\mathrm{Mg}^{2+}$ concentration that caused maximal relative response to $\mathrm{LH}$ varied from one membrane batch to another and were optimal only over a very narrow range of $\mathrm{Mg}^{2+}$ concentration. It should be pointed out that optimal $\mathrm{Mn}^{2+}$ effects appeared to be independent of $\mathrm{Mg}^{2+}$ concentration 10 to $5 \mathrm{mM}$, data not shown).

We also studied (fig. 9) the effects of $\mathrm{Mg}^{2+}$ concentrations on the doseresponse curve of $\mathrm{LH}$. Cyclic AMP production increased with increasing $\mathrm{Mg}^{2+}$ concentrations. The hormone decreased the $\mathrm{Mg}^{2+}$ concentrations required to half maximally stimulate $A C$ activity from 0.75 to $0.25 \mathrm{mM}$.
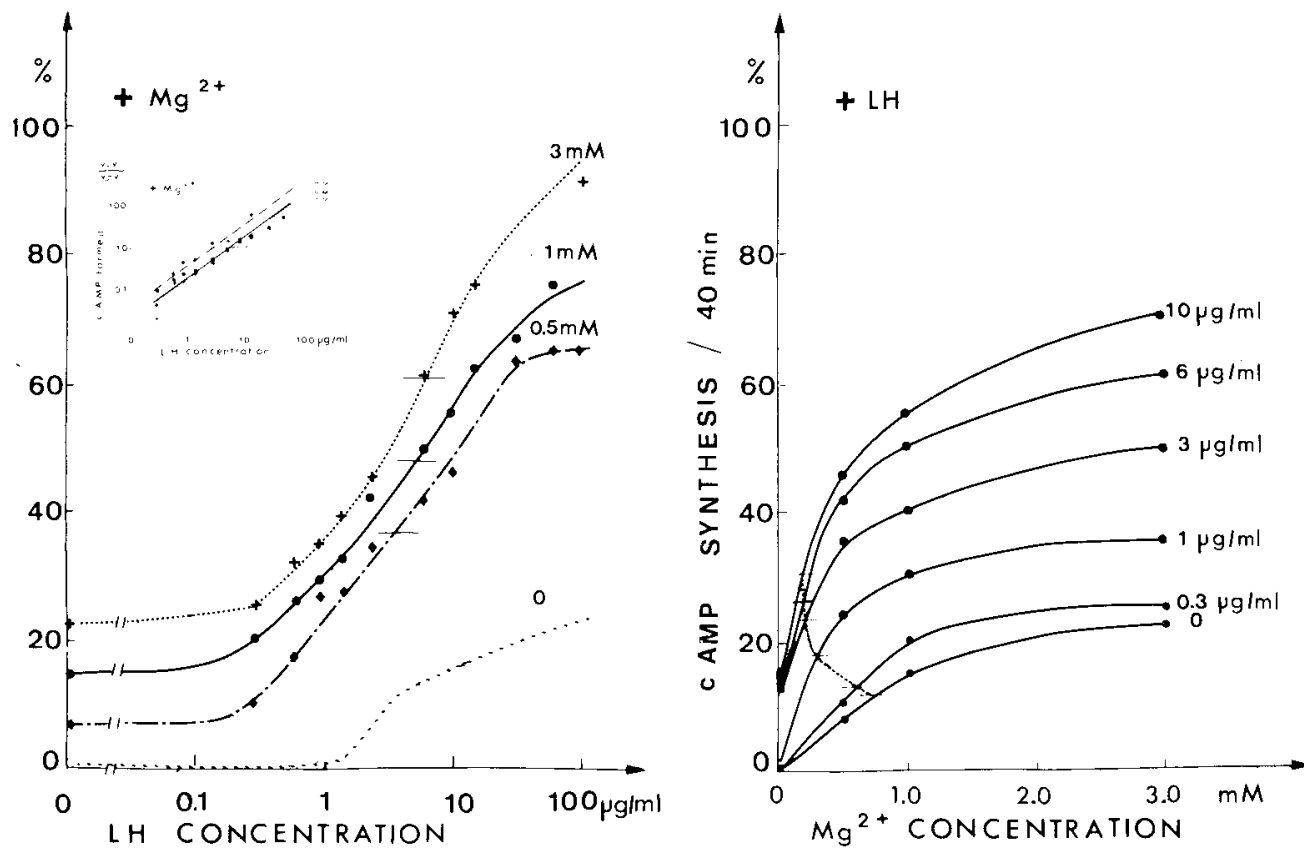

FIG. 9. - Effect of the addition of varying concentrations of $\mathrm{LH}_{\text {and }} \mathrm{Mg}^{2+}$ on cAMP production. ATP present was $0.5 \mathrm{mM}$. Inset : Hill plots of the proportional sections of the dose-response curves shown on the left panel.

Further studies were conducted to explore $\mathrm{Mg}^{2+}(0$ to $5 \mathrm{mM})$ dependence of stimulated AC with increasing ATP concentrations $(0.1$ to $0.6 \mathrm{mM})$ in the presence or absence of LH (fig. 10). The effects of increasing ATP concentrations depended on the presence or absence of $\mathrm{LH}$. The hormone seemed to diminish the apparent ATP concentration required for half maximal stimulation. With the $\mathrm{Mg}^{2+}$ concentrations used, relative $\mathrm{LH}$ stimulation decreased at increasing ATP 
concentrations higher than $300 \mu \mathrm{M}$. In a first approximation, our results seemed to indicated that $\mathrm{LH}$ in the presence of GMP-P(NH)P might give the catalytic subunit the ability to utilize Mg ATP as a substrate by increasing the apparent affinity of the catalytic site.

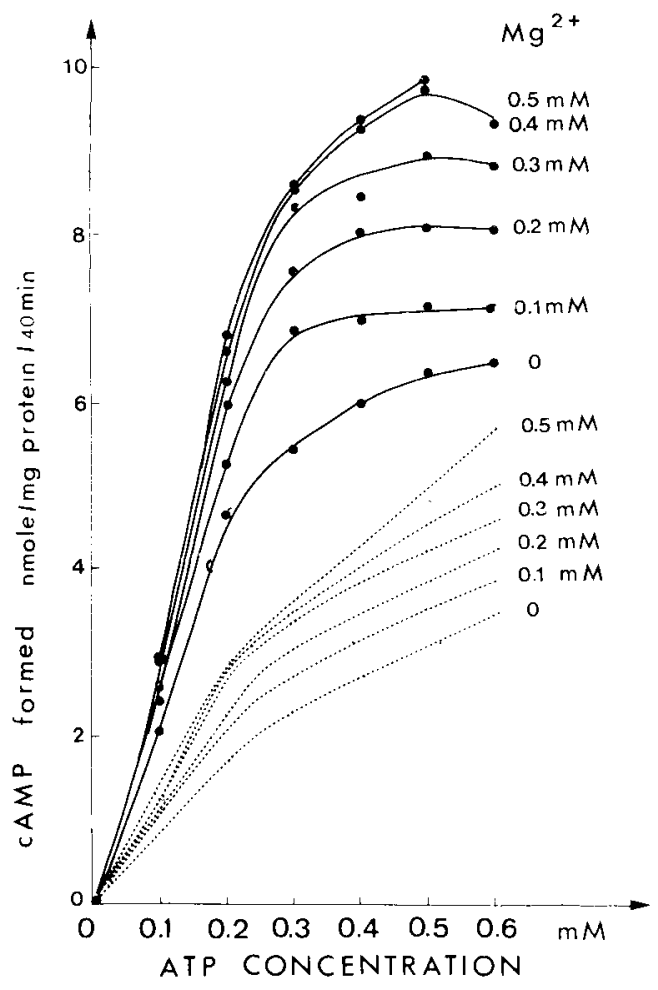

FIG. 10. - ATP dose-response curves of cAMP production stimulated by GMP. $P(N H) P(10 \mu \mathrm{M})(0)$ or GMP-P $(N H) P$ $(10 \mu \mathrm{M})+L H(10 \mu \mathrm{g} / \mathrm{ml})(\bullet)$ in the presence of different concentrations of $\mathrm{Mg}^{2+}$.

\section{Discussion.}

In the present studies we have described the properties of an LH-responsive adenylate cyclase in plasma membranes obtained from isolated interstitial cells of the rat testis. Both GTP and GMP-P(NH)P enhanced the production of cAMP when no hormone was added, as observed in rabbit corpus luteum (Abramowitz and Birnbaumer, 1982). The effects of GTP differed from those of GMP-P(NH)P ; the biphasic response to GTP also observed by Dufau et al. (1980) might be explained by the conversion of GTP to GDP in semi-purified membranes of testicular interstitial cells; the stimulatory and inhibitory regulatory components (Ns, $\mathrm{Ni)}$ are GTP-degrading protein (see review of Birnbaumer et al., 1985). GTP causes bimodal regulation of $A C$ in other cell types, and this effect appears to result from an involvement of $\mathrm{Ni}$ (Cooper, 1982 ; Cooper et al., 1979). The possibility that GTP inhibits cyclase activity via $\mathrm{Ni}$ cannot be ruled out, and further studies 
will be required to investigate the existence of such a mechanism in the interstitial cell adenylate cyclase system of the rat testis.

LH and GMP-P(NH)P acted synergically. It should be pointed out that the LH concentration required to stimulate the enzyme after membrane purification was higher than that observed when the synthesis of cAMP was studied in intact cells. Similarly, Birnbaumer et al. (1976) observed a very low apparent LH affinity for rat ovarian plasma membranes.

GMP-P(NH)P had no significant effect on the LH concentration needed to obtain half maximal activation ( $\mathrm{Ka}$ app) or on relative stimulation by $\mathrm{LH}$. In contrast, GMP-P(NH)P in rabbit corpus luteum seems to alter the Ka app for LH (Abramowitz and Birnbaumer, 1982) ; this discrepancy may reflect a species difference.

In the absence of hormonal stimuli, the interstitial cell adenylate cyclase of the rat testis responded slowly to GMP-P(NH)P; this finding is in contrast to reports by Dufau et al. (1980) but agrees with the general properties described for most adenylate cyclase systems (see review of Birnbaumer et al., 1985). Our results are inconsistent with the hypothesis that activation by GMP-P(NH)P leads to the irreversible activation of testicular interstitial cell adenylate cyclase in the complete sense of the term ; similar observations were reported by Londos and Preston (1977) and Birnbaumer et al. (1980) using liver plasma membranes. The slow rate of activation by GMP-P(NH)P was accelerated by $\mathrm{LH}$, in agreement with studies of other hormone-dependent adenylate cyclase systems; this effect of hormonal stimulation has been explained by the enhancement of nucleotide exchange (see review of Birnbaumer et al., 1985).

There is now considerable evidence indicating that, in addition to guanine nucleotides, $\mathrm{Mg}^{2+}$ plays a key role in $\mathrm{Ns}$ and $\mathrm{Ni}$ regulation of the activity of the catalytic component (Northup et al., 1982 ; Abramowitz and Birnbaumer, 1982 ; Codina et al., 1983). Evidence for the existence of $\mathrm{Mg}^{2+}$ binding sites on $\mathrm{Ns}$ and $\mathrm{Ni}$ has been reported (lyengar and Birnbaumer, 1982 ; Bockaert et al., 1984). In addition, a divalent cation binding site on the catalytic subunit has been shown (Somkuti et al., 1982).

The experiments presented in this paper also demonstrate that divalent cations play a major role in modulating enzyme activity in interstitial cells from the rat testis. At optimal concentrations of divalent cations, adenylate cyclase activity is greater when measured in the presence of $\mathrm{Mn}^{2+}$ than in the presence of $\mathrm{Mg}^{2+}$ ions. Independent lines of evidence from other adenylate cyclase systems suggest that $\mathrm{Mn}^{2+}$ ions may be necessary for the expression of the enzyme activity of the " bare " catalytic unit. The activation process of adenylate cyclase activity is apparent in the presence of $\mathrm{Mg}$ ATP if the catalytic subunit is coupled to a $\mathrm{N}$ protein, but requires the use of $\mathrm{Mn}$ ATP as a substrate in systems devoid of functional, active $\mathrm{N}$ proteins (Bourne et al., 1975 ; Neer, 1978 ; Stengel et al., 1982). From our data, the criterion of $\mathrm{Mn}^{2+} v s \mathrm{Mg}^{2+}$ activity might not be simple and absolute enough to distinguish the isolated $\mathrm{C}$ unit from the NC complex.

As shown in the ovary (Birnbaumer et al., 1976), LH stimulation of testicular interstitial cell membrane adenylate cyclase is closely dependent on the ATP and $\mathrm{Mg}^{2+}$ concentrations used. We have shown (1) that there is a complex relations- 
hip between adenylate cyclase, ATP and $\mathrm{Mg}$ ions, (2) that the dependence of cAMP synthesis on ATP concentrations differs according to whether LH is present or absent, (3) that in the presence of guanine nucleotides $\mathrm{LH}$ lowers apparent $\mathrm{Mg}$ ion requirement, and that (4) an excess of $\mathrm{Mg}^{2+}$ and $\mathrm{Mn}^{2+}$ inhibits $\mathrm{LH}$ stimulation of cAMP production.

In conclusion, the semipurified interstitial cell membranes of the rat testis are an excellent model for studying the effects of $\mathrm{LH}$ agonists and antagonists on adenylate cyclase activity and the hormonal regulation of the adenylate cyclase system in these cells.

Recu en juin 7985.

Accepté en décembre 1985.

Acknowledgements. - We are particularly grateful to Dr. Dominique Pantaloni for his constant interest in this work. We wish to thank Dr. J. Simonin for his advice on adenylate cyclase assay, Dr. Jutisz who kindly provided the ovine LH and Mr. M. Poissonnier who prepared it. This study was supported in part by Grant 9183005 from " Fondation de Recherche en Hormonologie ", Fresnes (France).

Résumé. Propriétés de l'adénylate cyclase de la membrane plasmique des cellules interstitielles du testicule de rat.

La régulation par la $\mathrm{LH}$, les nucléotides guanyliques et les cations divalents de l'activité adénylate cyclase $(\mathrm{AC})$ de membranes plasmiques de cellules interstitielles du testicule de rat a été étudiée. L'enzyme peut être activée par le GTP et le GMP-P(NH)P ; l'activation par le GTP est faible et biphasique et ce nucléotide est rapidement hydrolysé par les membranes. L'activation par le GMP-P(NH)P est environ 10 fois supérieure à celle obtenue avec le GTP. Le GDPRis ne stimule pas I'AC. En présence de GMP-P(NH)P, la vitesse stationnaire de production d'AMPc n'est atteinte qu'après environ $20 \mathrm{~min}$; cette période de latence est indépendante de la concentration de nucléotide. L'addition de GDPßS, 17 min après I'addition de GMP-P(NH)P conduit à une diminution immédiate de la vitesse de production d'AMPc ; cependant l'activité 40 min plus tard reste supérieure à celle obtenue si on ajoute simultanément (à $t=0)$ GMP-P(NH)P and GDP $\beta S$ S. L'état d'activation atteint avec le GMP-P(NH)P n'est donc pas strictement irréversible.

La LH et le GMP-P(NH)P agissent d'une manière synergique sans que le nucléotide modifie la concentration d'hormone nécessaire à l'obtention de la demi-stimulation maximale de l'enzyme ( $\mathrm{Ka}$ app.). La $\mathrm{LH}$ abolit la période de latence observée dans la cinétique de stimulation par le GMP-P(NH)P. L'activation de l'adénylate cyclase par la LH est étroitement dépendante des concentrations en $\mathrm{Mg}^{2+}$ et en ATP. L'hormone diminue la concentration en ion $\mathrm{Mg}$ nécessaire à l'obtention de la demi-stimulation maximale de l'enzyme.

Les membranes plasmiques de cellules interstitielles du testicule de rat sont un excellent modèle pour l'étude de la régulation de l'AC par LH.

\section{References}

ABRAMOWITZ J., BIRNBAUMER L., 1982. Properties of the hormonally responsive rabbit luteal adenyl cyclase : effects of guanine nucleotides and magnesium ion on stimulation by gonadotropin and catecholamines. Endocrinology, 110, 773-781.

ABRAMOWITZ J., IYENGAR R., BIRNBAUMER L., 1982. Guanine nucleotide and magnesium on regulation of the interaction of gonadotropic and $\beta$-adrenergic receptors with their hormones : a comparative study using a single membrane system. Endocrinology, 110, 336-346. 
BIRNBAUMER L., CODINA J., MATTERA R., CERIONE R. A., HILDEBRANDT J. D., SUNYER T., ROJAS F. J., CARON M. G., LEFKOWITZ R. J., IYENGAR R., 1985. Regulation of hormone receptors and adenyl cyclases by guanine nucleotide binding $\mathrm{N}$ proteins. Rec. Progr. Horm. Res., 41, 41-98.

BIRNBAUMER L., KIRCHICK H. J., 1983. Regulation of gonadotropic action : the molecular mechanisms of gonadotropin-induced activation of ovarian adenylyl cyclase, 287. In G. S. GREENWALD, P. F. TERRANOVA, Factors regulating ovarian function. Raven Press, N.Y.

BIRNBAUMER L., SWARTZ T. L., ABRAMOVITZ J., MINTZ PH. W., IYENGAR R., 1980. Transient and steady state kinetics of the interaction of guanyl nucleotides with the adenylate cyclase system from rat liver plasma membranes. J. biol. Chem., 255, 3542-3551.

BIRNBAUMER L., YANG P. Ch., HUNZICKER-DUNN M., BOCKAERT J., DURAN J. M., 1976. Adenylyl cyclase activities in ovarian tissues. I. Homogenization and conditions of assay in Graafian follicles and corpora lutea of rabbits rats and pigs : regulation by ATP and some comparative properties. Endocrinology, 99, 163-184.

BOCKAERT J., CACITAN B., SEBBEN-PEREZ M., 1984. Hormonal inhibition of adenylate cyclase. A crucial role for $\mathrm{Mg}^{2+} \mathrm{Mol}$. Pharmacol., 26, 180-186.

BOURNE H. R., COFFINO P., TOMKINS G. M., 1975. Selection of a variant lymphoma cell deficient in adenylate cyclase. Science, 187, 750-751.

CATT K. J., DUFAU M. L., 1973. Spare gonadotropin receptors in rat testis. Nature, New Biol., 244, 219-221.

CODINA J., HILDBRANDT J., IYENGAR R., BIRNBAUMER L., SAKURA R. D., MANCLARK Ch. R., 1983. Pertursis toxim substrate the putative Ni component of adenylate cyclase is an $\alpha \beta$ heterodimer regulated by guanine nucleotide and $\mathrm{Mg}$. Proc. nat. Acad. Sci. U.S.A., 80, 4276-4280.

COOPER D. M. F., 1982. Biomodal regulation of adenylate cyclase. FEBS Letters, 138, 157-164.

COOPER D. M. F., SCHLEGEL W., LIN M. C., RODBELL M., 1979. The fat cell adenylate cyclase system ; characterization of its bimodal regulation by GTP. J. biol. Chem., 254, 8927-8931.

DE LA LLOSA-HERMIER M. P., DE LA LLOSA P., HERMIER C., 1977. Studies of the binding activity to different gonadal receptors of ovine luteinizing hormone (LH) after chemical modification of lysine residues. Gen. comp. Endocrinol., 31, 302-306.

DE LA LLOSA-HERMIER M. P., TERTRIN-CLARY C., EVRARD-HEROUARD M., COLLEAUX Y., HERMIER C., DE LA LLOSA P., 1980. A comparative study of the action of several lutropin derivatives on rat Leydig cells. Acta endocr., 93, 250-256.

DUFAU M. L., BAUKAL A. J., CATT K. J., 1980. Hormone-induced guanyl nucleotide binding and activation of adenylate cyclase in Leydig cells. Proc. nat. Acad. Sci., U.S.A., 77, 5837-5841.

EZRA E., SALOMON Y., 1981. Mechanism of desensitization of adenylate cyclase by lutropin. Impaired introduction of GTP into the regulatory site. J. biol. Chem., 256, 5377-5382.

IYENGAR R., BIRNBAUMER L., 1982. Hormone receptor modulates the regulatory component of adenylyl cyclase by reducing its requirement for $\mathrm{Mg}^{2+}$ and enhancing its extent of activation by guanine nucleotides. Proc. nat. Acad. Sci., U.S.A., 79, 5179-5183.

JUTISZ M., COURTE C., 1968. Hormone lutéinisante (LH) de mouton. Obtention à l'état apparemment homogène, étude physico-chimique et biologique. Gen. comp. Endocrinol., 11, 562 574.

LEFKOWITZ R. J., CARON M. G., 1975. Characteristics of 5' -guanylyl imidodiphosphate-activated adenylate cyclase. J. biol. Chem., 250, 4418-4422.

LEVI S. N., DIX C. J., THOMAS M. G. J., COOKE B. A., 1982a. Isolation and characterization of plasma membranes containing $\mathrm{LH}$-sensitive adenylate cyclase from a Leydig cell tumour. Int. J. Andrology, 5, 557-569.

LEVI S. N., SCHUMACHER M., DIX C. J., THOMAS M. G., COOKE B. A., 1982b. Isolation and characterization of plasma membranes containing $\mathrm{LH}$-sensitive adenylate cyclase from a Leydig cell tumour. Int. J. Andrology, 5, 570-578.

LONDOS C., PRESTON M. S., 1977. Activation of the hepatic adenylate cyclase system by divalent cations. J. biol. Chem., 252, 5957-5961.

LOWRY O. H., ROSEBROUGH N. W., FARR A. L., RANDALL R. J., 1951. Protein measurement with the folin phenol reagent. J. biol. Chem., 193, 265-275.

MINTZ Y., AMIR A., AMSTERDAM A. K., LINDNER H. R., SALOMON Y., 1978. Properties of 
LH-sensitive adenylate-cyclase in purified plasma membranes from rat ovary. Mol. cell. Endocrinol., 11, 265-283.

NEER E. J., 1978. Size and detergent binding of adenylate cyclase from bovine cerebral cortex. J. biol. Chem., 253, 1498-1502.

NISHIZUKA J., LIPMANN F., LUCAS-LENARD J., 1968. Isolation and properties of the Escherichia coli amino acid polymerizing enzymes. Methods Enzymol., 12B, 713.

NORTHUP J. K., SMIGEL M. D., GILMAN A. G., 1982. The guanine nucleotide activating site of the regulatory component of adenylate cyclase. Identification by ligan binding. J. biol. Chem., 257, 11416-11423.

SCHRAMM M., RODBELL M., 1975. A persistent active state of the adenylate cyclase system produced by the combined actions of isoproterenol and guanylyl imidodiphosphate in frog erythrocyte membranes. J. biol. Chem., 250, 2232-2237.

SOMKUTI S. C., HILDEBRANDT J. D., HERBER J. T., IYENGAR R., 1982. Divalent cation regulation of adenylyl cyclase; an allosteric site on the catalytic component. J. biol. Chem., 257. 6387-6393.

STENGEL D., GUENET L., HANOUNE J., 1982. Proteolitic solubilization of adenylate cyclase from membranes deficient in regulatory component. J. biol. Chem., 257, 10818-10826.

WHITE A. A., 1974. Separation and purification of cyclic nucleotides by alumina column chromatography. Methods Enzymol., 38, 41-46. 